\title{
Mucolipidosis III (Pseudo-Hurler Polydystrophy): Multiple Lysosomal Enzyme Abnormalities in Serum and Gultured Fibroblast Gells
}

\author{
George H. Thomas ${ }^{\mid 281}$, Harold A. Taylor, Linda W. Reynolds, and Caroi. S. Miller \\ Departments of Pediatrics and Medicine, The Johns Hopkins University School of Medicine and The John F. Kennedy Institute, \\ Baltinore, Maryland, US:
}

\begin{abstract}
Extract
Four patients with the clinical findings of mucolipidosis III were studied. Cultured skin fibroblast cells from three of these four patients were low in each of the five lysosomal enzyme activities measured. The ranges of the enzyme activities in these three patients were as follows: $N$-acetyl- $\beta$-glucosaminidase $(11-19 \%$ of normal), $\beta$-galactosidase (26-33\% of normal), $\alpha$-fucosidase $(31-55 \%$ of normal), $\alpha$-mannosidase (53-62\% of normal), and arylsulfatase A (16-21\% of normal).

In contrast, marked increases in the same enzyme activities were found in serum samples from the same patients. These include $N$-acetyl- $\beta$-glucosaminidase (7-16 times normal), $\beta$-galactosidase (8-11 times normal), $\alpha$-fucosidase (5-10 times normal) and arylsulfatase A (14-24 times normal). Similar increases in the enzyme activities were also found in serum of patient 1; however, the changes were less dramatic.

An electrophoretic analysis of one of these enzymes ( $N$-acetyl- $\beta$-glucosaminidase) revealed an abnormal pattern in the cultured fibroblast extracts; however, the presence of a normal pattern in the serum samples suggests that this is not due to an alteration in the primary amino acid sequence.
\end{abstract}

\section{Speculation}

The lysosomal enzyme activities in serum and fibroblast extracts from the mucolipidosis III patients reported here are very similar to those found previously in mucolipidosis II (I-cell) patients. This suggests that the nature of the defect may be very similar in these two distinct disorders.

\section{Introduction}

Pseudo-Hurler polydystrophy (pseudopolydystrophy) is an inherited disorder exhibiting some of the features of both the mucopolysaccharidoses and the sphingolipidoses; hence, its reccnt designation as mucolipidosis III [16].

The clinical features of this disorder include the following: joint stiffness associated with limitation of mobility, corneal opacitics by slit lamp examination, milcl skeletal abnormalities, minimal to moderate coarseness of facial features, mild mental retardation, and normal mucopolysaccharide excretion $[8,9,13,17]$.

Although the pathogenesis of this disorder remains obscure, the demonstration of vacuolated bone marrow cells [8], gross alterations in the ultrastructure of direct comnective tissue cells [11], and the presence of inclusion cells associated with gross ultrastructure changes 
in cultured fibroblasts [19] suggests that mucolipidosis III may be a "storage disorder" associated with abnormal lysosomal function.

In support of this suggestion, the findings reported here also indicate that there are marked alterations in a number of lysosomal enzyme activities in the serum and the fibroblast cells obtained from mucolipidosis III patients. In addition, evidence is presented which shows that these changes in enzyme activity are very similar to those seen in mucolipidosis II (I-cell disease) $[6]$.

\section{Materials and Methods}

\section{Patients}

The four patients with the clinical features of mucolipidosis III included in this report were studicd by the division of Medical Genetics of The Johns Hopkins Hospital [22].

These include the following: patient 1 (MR, J.H.H. 133-99-83); patient 2 (CW, J.H.H. 124-35-91); patient 3 (RW, J.H.H. 124-35-88); and patient 4 (BS, J.H.H. 146-95-09). A detailed description of the clinical findings in each of these patients has been reported elsewhere $[9,13,15]$.

In addition, cultured fibroblast cells and scrum from a patient with mucolipidosis II were included in this study for the purpose of comparison. The clinical, biochemical, and ultrastructural findings in this patient are described elsewhere $[5,7,14]$.

\section{Methods}

Fibroblast cells were cultured from skin biopsies obtained from the patients and the normal subjects as described elsewhere [19]. All cultures were harvested with trypsin and analyzed 7 days after subculture, and, when possible, were matched for total "culture age."

Table I. Assay conditions for enzymes in cultured fibroblast extracts using $p$-nitrophenyl substratcs

\begin{tabular}{|c|c|c|c|c|c|c|}
\hline \multirow[b]{2}{*}{ Enzyme } & \multicolumn{2}{|c|}{$\begin{array}{l}\text { Citrate }{ }^{1} \text { phos- } \\
\text { phate buffer }\end{array}$} & \multicolumn{2}{|c|}{ Substrate } & \multirow{2}{*}{$\begin{array}{l}\text { Cell } \\
\text { ex- } \\
\text { tract, } \\
\text { ml }\end{array}$} & \multirow{2}{*}{$\begin{array}{c}\text { Incuba } \\
\text { tion } \\
\text { time, } \\
\text { min }\end{array}$} \\
\hline & $\begin{array}{c}\text { vol- } \\
\text { ume, } \\
\text { m! }\end{array}$ & $\mathrm{pH}$ & $\begin{array}{c}\text { Vol- } \\
\text { ume, } \\
\text { ml }\end{array}$ & $\begin{array}{l}\text { Concen- } \\
\text { tration, } \\
\text { mM }\end{array}$ & & \\
\hline$\alpha$-Fucosidasc & 0.2 & 5.6 & 0.6 & 5 & 0.2 & 60 \\
\hline$\alpha$-Mannosidase & 0.2 & 3.6 & 0.6 & 6.7 & 0.2 & 60 \\
\hline$\beta$-Galactosidasc & 0.2 & 3.6 & 0.6 & 5 & 0.2 & 30 \\
\hline $\begin{array}{l}N \text {-Acetyl- } \beta \text { - } \\
\text { glucosamini- } \\
\text { dase }\end{array}$ & 0.18 & 4.0 & 0.8 & 3.8 & 0.02 & 30 \\
\hline
\end{tabular}

1 Prepared from $0.1 \mathrm{~m}$ citric acid and $0.2 \mathrm{~m}$ dibasic sodium phosphate as described by Gomori [2].
Mycoplasma screening was carried out on some (but not all) of the fibroblast cultures from both the patient and the control group. No evidence of mycoplasma infection was found in these cultures.

For enzyme analyses, cells from three confluent cultures in 250-ml tissue culture flasks [23] were pooled, washed three times with phosphate-buffered saline $(\mathrm{pH}$ 7.2), and centrifuged. The washed pellet was suspended in $3 \mathrm{ml}$ distilled water and the cells were disrupted by ultrasonication. Extracts to be used for electrophoretic analysis were then centrifuged for $10 \mathrm{~min}$ at $5,000 \times g$ at $3-5^{\circ}$. For direct enzyme analysis, however, the centrifugation step was found to be unnecessary and was, therefore, omitted.

Serum samples were obtained in the usual manner and frozcn until needed.

Both the total and the heat labile fractions of the $N$-acetyl- $\beta$-glucosaminidase activity were measured according to the method of Kaback [4] as described elsewhere [7]. The electrophoretic analysis was performed on Cellogel [24] strips $(7.8 \mathrm{~cm} \times 15 \mathrm{~cm} \times 500 \mu \mathrm{m})$ in 0.035 M citric acid-sodium citrate buffer $\mathrm{pH} 5.5$ for 2.5 hr at 9.5-12.5 ma (approximate voltage \pm 150 ) at room temperature according to the procedure of Rattazzi and Davidson [12]. The fluorescence of the enzyme product was enhanced by the substitution of ammonia vapors for the formol and glycine-carbonate treatments of the original proceclure.

Arylsulfatase A activity was measured by a modification of the method of Baum et al. [1]. This consisted of incubating $0.2 \mathrm{ml}$ serum or cell extract with $0.3 \mathrm{ml}$ distilled water and $0.5 \mathrm{ml}$ reagent $\mathrm{A}(0.01 \mathrm{M} p$-nitrocatechol sulfate in $0.5 \mathrm{~m}$ sodium acetate-acetic acid buffer which contained $5 \times 10^{-4} \mathrm{M}$ sodium pyrophosphate and $10 \%$ sodium chloride, $\mathrm{pH} 5.0$ ) for $1 \mathrm{hr}$ at $37^{\circ}$. At the end of this time $1.5 \mathrm{ml} 1 \mathrm{~N} \mathrm{NaOH}$ were added and the absorbance was determined at $515 \mathrm{~nm}$. Blank values were obtained by incubating the sample and reagent $\mathrm{A}$ in separate tubes before the addition of the $1 \mathrm{~N} \mathrm{NaOH}$.

The $\beta$-galactosidase, $N$-acetyl- $\beta$-glucosaminidase, $\alpha$ fucosidase, and $\alpha$-mannosidase activities in the cultured fibroblast cells were determined spectrophotometrically by measuring the free $p$-nitrophenol released from the appropriate glycosidic derivatives dissolved in distilled water under the conditions given in Table I. After incubation at $37^{\circ}$ for the appropriate period of time, the reactions were terminated by the addition of $0.4 \mathrm{ml} 0.25 \mathrm{M}$ glycine-carbonate buffer, $\mathrm{pH} 10$, and the optical clensity was measured at 400 $\mathrm{nm}$. All reactions were run in duplicate with the appropriate controls. 
The serum $\beta$-galactosidase activity was determined by incubating $0.1 \mathrm{ml}$ serum with $0.4 \mathrm{ml}$ 4-methylumbelliferyl- $\beta$-D-galactopyranoside $(2 \mathrm{~mm}$ in citrate-phosphate buffer, $\mathrm{pH} \mathrm{3.2)} \mathrm{for} 30 \mathrm{~min}$ at $37^{\circ}$. At the end of this time, $0.1 \mathrm{ml}$ of the above solution was added to 2.5 $\mathrm{ml} 0.1$ м 2-amino-2-methyl-1-propanol-HCl buffer, $\mathrm{pH}$ 10.3 , and the fluorescence was determined.

The serum $\alpha$-fucosidase activity was determined by a modification $(0.9 \mathrm{ml}$ glycine-carbonate buffer in the final step and determination of absorbance at $400 \mathrm{~nm}$ ) of the method of Zielke et al. [21].

\section{Results}

Each of the five lysosomal enzyme activities measured in the extracts of cultured fibroblast cells, obtained from the mucolipidosis III patients 2-4 (except $\alpha$-fucosidase in patients 2 and 3), were found to be greatly reduced (Table II). It was also found that, although there was a generalized reduction in the enzyme activities in the fibroblast cells from patient 1 , the decrease was less marked than that found in the other mucolipidosis III patients and in several cases was very close to the low normal values.

In contrast to the decreased values in the fibroblast extracts, each of the enzymes measured in serum samples obtained from the same patients were increased several times that of the normal values (Tables III and IV).

As can be seen from the results given in Tables II and III, the changes found in the fibroblast extracts and the serum samples from the mucolipidosis patients 2-4 were very similar to those found in the patient with mucolipidosis II (I-cell disease).

A detailed analysis of the heat stability of one of these enzymes ( $N$-acetyl- $\beta$-D-glucosaminidase), utilizing the 4-methylumbelliferyl- $N$-acetyl- $\beta$-D-glucosaminide substrate, was also carried out. As is shown in Table IV, only $19-24 \%$ of the total activity in the serum from the mucolipidosis III patients was destroyed by heating for $2 \mathrm{hr}$ at $52^{\circ}$. This compares with an average value of $55 \%$ inactivation for serum from normal control subjects when treated in an identical manner.

An electrophoretic analysis of this enzyme in serum demonstrated the presence of two distinct bands of activity. Except for the marked increase in activity, these bands appeared to be identical with the faster moving bands (A and $\mathrm{I}_{2}[25]$ ) routinely seen in normal serum samples (Fig. 1) [10]. In these samples, however, the $\mathrm{I}_{2}$ band, not the $\mathrm{A}$ band, accounted for the major proportion of the activity.
Table $I I$. Lysosomal cnzyme activities in extracts of cultured fibroblast cells

\begin{tabular}{lccccc}
\hline Patients & $\begin{array}{c}N \text {-Acetyl- } \\
\beta \text {-glucosa- } \\
\text { minidase }^{1}\end{array}$ & $\begin{array}{c}\beta \text {-Galac- } \\
\text { tosidase }^{1}\end{array}$ & $\begin{array}{c}\alpha-\text { Fuco- }_{\text {sidase }^{1}} \\
\begin{array}{c}\alpha \text {-Man- } \\
\text { nosidase }^{1}\end{array}\end{array} \begin{array}{c}\text { Arylsul- } \\
\text { fatase A }^{2}\end{array}$ \\
\hline $\begin{array}{c}\text { Mucolipidosis II } \\
\text { Patient 1 }\end{array}$ & 3,030 & 492 & 7 & 133 & 173 \\
Patient 2 & 917 & 148 & 13 & 80 & 75 \\
Patient 3 & 829 & 170 & 11 & 93 & 77 \\
Patient 4 & 535 & 186 & 7 & 87 & 59 \\
Mucolipidosis II & 612 & 106 & 8 & 77 & 17 \\
Control (mean) & 4,725 & 563 & 24 & 151 & 368 \\
& $(n=17)$ & $(n=22)$ & $(n=15)$ & $(n=19)$ & $(n=20)$ \\
Control (range) & $3,248-7,689$ & $213-843$ & $12-49$ & $114-262$ & $170-684$ \\
& $(n=17)$ & $(n=22)$ & $(n=15)$ & $(n=19)$ & $(n=20)$ \\
\hline
\end{tabular}

I Nanomoles of $p$-nitrophenol released per milligram of protein per hour at $37^{\circ}$ 2 Nanomoles of nitrocatechol released per milligram of protein per hour at $37^{\circ}$

Table III. Lysosomal enzyme activities in serum.

\begin{tabular}{lccr}
\hline Patients & $\begin{array}{c}\beta \text {-Galac- } \\
\text { tosidase }^{1}\end{array}$ & $\alpha$-Fucosidase & $\begin{array}{c}\text { Arylsul- } \\
\text { fatase A }^{3}\end{array}$ \\
\hline $\begin{array}{l}\text { Mucolipidosis III } \\
\text { Patient 1 }\end{array}$ & 105 & 736 & 319 \\
Patient 2 & 270 & 2,224 & 1,237 \\
Patient 3 & 265 & 1,408 & 1,373 \\
Patient 4 & 195 & 2,688 & 812 \\
Mucolipidosis II & 760 & 2,576 & 2,386 \\
Controls & 26 & 277 & 57 \\
$\quad$ (mean) (n= & & & \\
12) & $12-61$ & $96-640$ & $10-186$ \\
Controls (range) & & & \\
$\quad(n=12)$ & & \\
\hline
\end{tabular}

${ }^{1}$ Nanomoles of 4-methylumbelliferone released by $1 \mathrm{ml}$ serum/ hr at $37^{\circ}$.

${ }^{2}$ Nanomoles of $p$-nitrophenol released by $1 \mathrm{ml}$ serum $/$ hr at $37^{\circ}$.

${ }^{3}$ Nanomoles of nitrocatechol released by $1 \mathrm{ml} \mathrm{serum} / \mathrm{hr}$ at $37^{\circ}$.

Table $I V . N$-Acetyl- $\beta$-glucosaminidase activity in serum.

\begin{tabular}{|c|c|c|c|c|c|}
\hline \multirow{2}{*}{ Patients } & \multirow{2}{*}{$\begin{array}{l}\text { Total } \\
\text { activity, } \\
\text { units }^{1}\end{array}$} & \multicolumn{2}{|c|}{$\begin{array}{c}\text { Heat-labile } \\
\text { component(s) }\end{array}$} & \multicolumn{2}{|c|}{$\begin{array}{c}\text { Heat-stable } \\
\text { component(s) }\end{array}$} \\
\hline & & $\%^{2}$ & Units ${ }^{1}$ & $\%^{2}$ & Units $^{1}$ \\
\hline \multicolumn{6}{|l|}{ Mucolipidosis III } \\
\hline Patient 1 & 4,997 & 26 & 1,299 & 74 & 3,748 \\
\hline Patient 2 & 12,118 & 19 & 2,242 & 81 & 9,876 \\
\hline Patient 3 & 8,048 & 15 & 1,207 & 85 & 6,840 \\
\hline Patient 4 & 5,365 & 24 & 1,288 & 76 & 4,077 \\
\hline $\begin{array}{l}\text { Controls (mean) } \\
\quad(n=20)\end{array}$ & 751 & 55 & 412 & 45 & 339 \\
\hline $\begin{array}{l}\text { Controls (range) } \\
\quad(n=20)\end{array}$ & $592-990$ & $50-62$ & & $50-38$ & \\
\hline
\end{tabular}

1 Nanomoles of 4 -methylumbelliferone produced per milliliter of serum per hour at $37^{\circ}$.

2 Average of activity destroyed by 2 and $3 \mathrm{hr}$ of incubation at $52^{\circ}$, pH 4.4 .

A similar analysis carried out on extracts of the fibroblast cells from the mucolipidosis III patients $2-4$ yielded results for the heat stability of the $N$-acetyl- $\beta$ D-glucosaminidase which were similar to those obtained in extracts of normal fibroblast cells (Table V). 

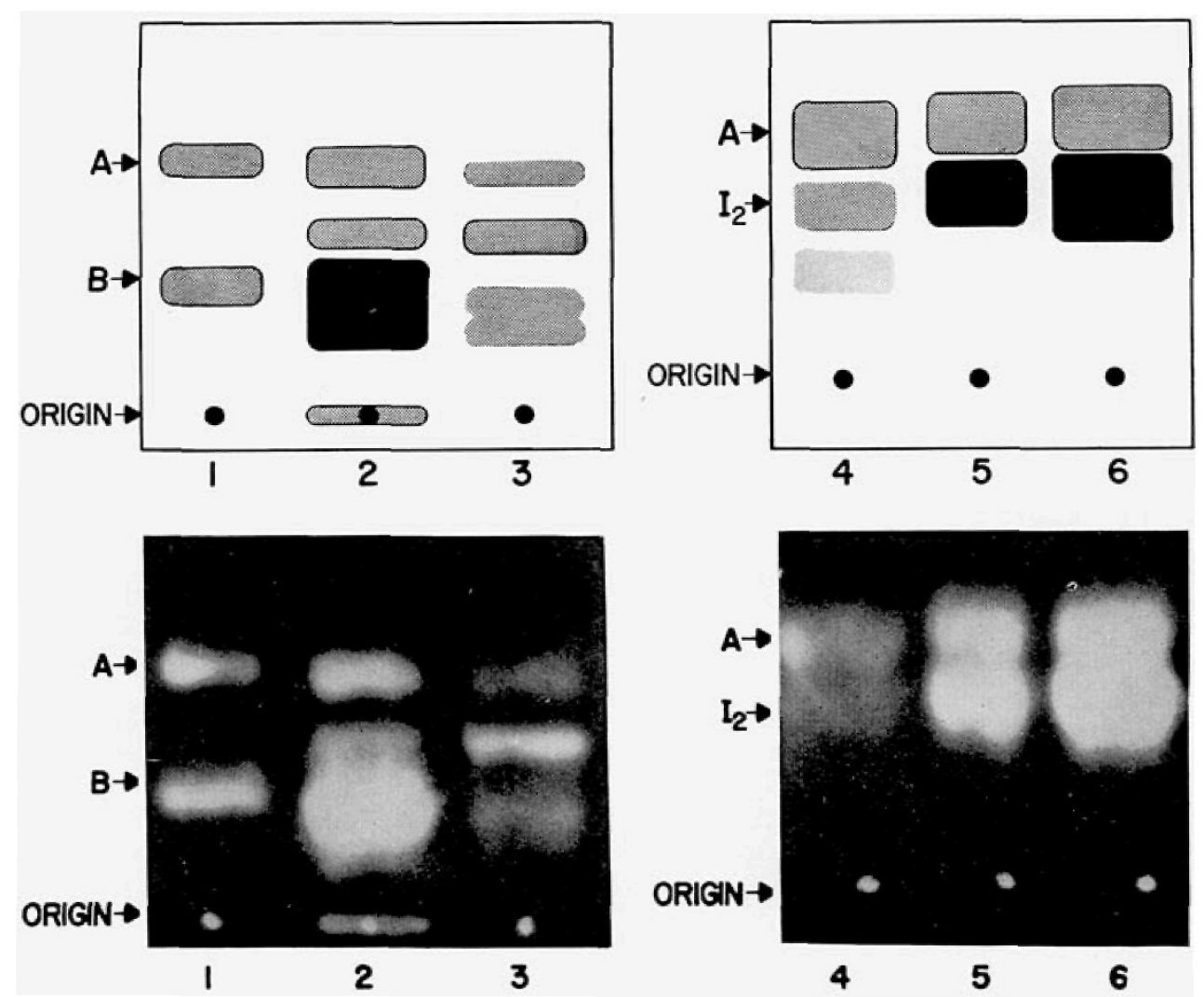

Fig. 1. Cellogel electrophoresis of $N$-acetyl- $\beta$-D-glucosaminidase. Lane $1: 2.5 \mu$ I (approximately $12.5 \mu$ g soluble protein) fibroblast cell extract from normal control subject. Lane 2:5 $\mu$ (approximately $25 \mu \mathrm{g}$ soluble protein) fibroblast cell extract from patient 1 with mucolipidosis III. Lane 3: $5 \mu \mathrm{l}$ (approximately $25 \mu \mathrm{g}$ soluble protein) fibroblast cell extract from patient 2 with mucolipidosis III. Lane 4: $10 \mu 1$ serum from normal control subject. Lane 5: $5 \mu \mathrm{l}$ serum from patient 1. Lane 6:5 $5 \mathrm{l}$ serum from patient 2. Note: The electrophoretic patterns of both the serum and cell extracts obtained from patients 3 and 4 were indistinguishable from those of patient 2 shown above.

Table V. $N$-Acetyl- $\beta$-glucosaminidase activity in cultured fibroblast cells

\begin{tabular}{|c|c|c|c|c|c|}
\hline \multirow{2}{*}{ Patients } & \multirow{2}{*}{$\begin{array}{c}\text { Total } \\
\text { activity } \\
\text { units }^{1}\end{array}$} & \multicolumn{2}{|c|}{$\begin{array}{l}\text { Heat-labile } \\
\text { component(s) }\end{array}$} & \multicolumn{2}{|c|}{$\begin{array}{c}\text { Heat-stable } \\
\text { component(s) }\end{array}$} \\
\hline & & $\%^{2}$ & Units $^{1}$ & $\%^{2}$ & Units ${ }^{1}$ \\
\hline \multicolumn{6}{|l|}{ Mucolipidosis III } \\
\hline Patient 1 & 2,005 & 20 & 401 & 80 & 1,604 \\
\hline Patient 2 & 492 & 53 & 259 & 47 & 232 \\
\hline Patient 3 & 469 & 58 & 272 & 42 & 197 \\
\hline Patient 4 & 473 & 45 & 212 & 55 & 260 \\
\hline $\begin{array}{l}\text { Controls (mean) } \\
\quad(n=2)\end{array}$ & 2,752 & 56 & 1,538 & 44 & 1,214 \\
\hline $\begin{array}{l}\text { Controls (range) } \\
\quad(n=2)\end{array}$ & $2,388-3,116$ & 56 & & 44 & \\
\hline
\end{tabular}

1 Nanomoles of 4-methylumbelliferone produced per milligram of soluble protein per hour at $37^{\circ}$.

2 Average of activity destroyed by 2 and $3 \mathrm{hr}$ of incubation at $52^{\circ}, \mathrm{pH} 4.4$.

In contrast, the results obtained on the cells from mucolipidosis patient 1 were repeatedly abnormal with only $20 \%$ of the enzyme being destroyed by heating for 2 hr at $52^{\circ}$.

In contrast with the two bands routinely detected in normal cell extracts, an electrophoretic analysis of the fibroblast extracts from patients $2-4$ repeatedly yielded at least three distinct bands of activity (Fig. 1). In each of these extracts the extra band moved between the two bands whose electrophoretic mobilities were identical with those seen in normal control subjects and were considered to represent the A and B bands (Fig. 1).

In patient 1 the pattern was characterized, not only by the presence of the intermediate band, but also by a very marked increase in the relative amount of the slowest moving (B) band (Fig. 1).

\section{Discussion}

We have found evidence previously which indicates that the "I-cell phenomenon" generally considered to be a unique feature of mucolipidosis II (I-cell disease) is also a characteristic feature of cultured fibroblast cells obtained from mucolipidosis III patients [19].

The findings reported here show that patients with 
these two disorders also have in common a number of biochemical alterations involving a variety of lysosomal enzymes.

Specifically, extracts of cultured fibroblast cells obtained from three of four patients with the clinical features of mucolipidosis III had a multiple enzyme deficiency very similar to that found in mucolipidosis II [6]. Moreover, as is the case in mucolipidosis II [20], there were marked increases in a number of lysosomal enzymes in serum samples from the same patients.

Also in agreement with the data obtained from study of a mucolipidosis II patient [7], is the finding that the increase (7-16 times normal) in the serum $N$-acetyl- $\beta$-D-glucosaminidase level was most prominent in the $\mathrm{I}_{2}$ band (11-29 times normal).

This alteration in the ratio of the $A$ activity to the $\mathrm{I}_{2}$ activity is believed to be the basis for the abnormal enzyme heat stability noted in the serum. This belief is based on the observation that the $I_{2}$ activity is stable under the conditions employed for the heat denaturation determination while the A activity is destroyed [10].

Yet another similarity is the observation that the decreased $N$-acetyl- $\beta$-D-glucosaminidase acitivity in the fibroblast extracts in both disorders is associated with an abnormal electrophoretic pattern [7]. In mucolipidosis III, however, the pattern differed from the pattern found in mucolipidosis II [7].

As discussed elsewhere [7], the abnormal electrophoretic pattern could be caused by any one of several mechanisms and at the present time the actual significance of this observation is obscure. The absence, however, of similar electrophoretic changes in the serum samples from the patients, as well as several from the parents studied, suggests that this is not due to inherited changes in the primary amino acid composition of the enzyme.

It is of note, however, that preliminary studies carried out on the parents of these patients indicate that the percentage of the heat labile (A) fraction of the $N$-acetyl- $\beta$-D-glucosaminidase is decreased in serum. An electrophoretic analysis of these samples, however, indicates that this alteration in ratio is due to an increase in the relative concentration of the heat stable $\mathrm{I}_{2}$ rather than an absolute decrease in the A fraction. As with the patients, no aberrant bands were noted in the serum of these parents. A detailed analysis of both serum and fibroblast cells from this group of parents is currently underway.

Patient 1, who also had the clinical features of mucolipidosis III, was also found to have abnormal bio- chemical changes; however, in many cases these changes differed in either quantity or quality from those found in the other three patients. The basis for these differences is not understood; however, they are in keeping with the finding that the cytologic and ultrastructural changes in this patient are less dramatic than those of the other three patients [19]. These observations have led to the suggestion that this could be due to genetic variability or heterogeneity [19]. It is also possible that this patient represents an entirely different biochemical disorder which is very similar clinically to mucolipidosis III. Additional studies based on both biochemical and clinical finclings should help clarify this question.

In summary, although mucolipidosis II and mucolipidosis III are clearly distinct disorders, they have very similar morphologic and biochemical alterations at the cellular level, and thus the nature of the defect may be very similar. It is, therefore, possible that the various hypotheses which have been proposed to explain the pathogenesis of mucolipidosis II (I-cell disease), i.e., cellular leakage [20] or defective site recognition [3] may also be of relevance in mucolipidosis III.

\section{Summary}

Five lysosomal enzymes were measured in fibroblast extracts and serum samples from four patients with mucolipidosis III. A multiple deficiency of several enzyme activities was found in the frbroblast cells obtained from three of these four patients which was very similar to that seen in mucolipidosis II (I-cell disease). In contrast, the serum levels of these same enzyme activities were greatly increased; this was again very similar to those levels found in mucolipidosis II.

The increased serum activity of one of these enzymes ( $N$-acetyl- $\beta$-glucosaminidase) resided in two electrophoretic bands with the characteristics of the $A$ and $I_{2}$ bands found in normal control serum. In contrast, the decreased level of this enzyme activity in fibroblast extracts was associated with an abnormal electrophoretic pattern.

\section{References and Notes}

1. Baum, H., Dodgson, K. S., And Spencer, B.: The assay of arylsulphatases $\mathrm{A}$ and $\mathrm{B}$ in human urine. Clin. Chim. Acta, 4: 453 (1959).

2. Gomori, G.: Preparation of buffers for use in enzyme studies. Methods Enzymol., 1: 138 (1955).

3. Hickman, S., and Neufeld, E. F.: A hypothesis for I-ccll disease: Defective hydrolases that do not enter lysosomes. Biochem. Biophys. Acta, 49: 992 (1972). 
4. KABACK, M. M.: Thermal fractionation of serum hexosaminidase: Applications to heterozygote detection and diagnosis of Tay-Sachs disease. In: V. Ginsburg: Methods of Enzymology, Vol. 28. (Academic Press, New York (in press)).

5. Kenyon, K. R., and Sensenbrenner, J. A.: Mucolipidosis II (I-cell disease): Ultrastructural observations of conjunctiva and skin. Invest. Ophthalmol., 10:555 (1971).

6. Leroy, J. G., Ho, M. W., MacBrinN, M. C., Zielke, K., JАCOB, J., AND O'BRIEN J. S.: I-cell disease: Biochemical studies. Pediat. Res., 6: 752 (1972).

7. Lie, K. K., Thomas, G. H., Taylor, H. A., and SensenbrenNER, J. A.: Analysis of $N$-acetyl- $\beta$-D-glucosaminidase in mucolipidosis II (I-cell disease). Clin. Chim. Acta (In press).

8. Maroteaux, P., and Lamy, M.: La pseudopolydystrophie de Hurler. Presse Med., 74: 2889 (1966).

9. Melhem, R., Dorst, J. P., Scott, C. I., JR., ANd McKusick, V. A.: Roentgen findings in mucolipidosis III (pseudo-Hurler polydystrophy). Radiology, 106: I53 (I973).

10. Price, R. G., and Dance, N.: The demonstration of multiple heat stable forms of $N$-acetyl- $\beta$-glycosaminidase in normal human serum. Biochim. Biophys. Acta, 271: 145 (1972).

11. Quigley, H. A., AND Goldberg, M. F.: Conjunctival ultrastructure in mucolipidosis III (pseudo-Hurler polydystrophy). Invest. Ophthalmol., 10: 568 (1971).

12. Ratrazzi, M. C., and Davidson, R. G.: Prenatal detection of Tay-Sachs disease. In: A. Dorfman: Antenatal Diagnosis, p. 207. (The University of Chicago Press, Chicago, 1972).

13. Scotr, C. I., Jr., and Grossman, M. S.: Pseudo-Hurler polydystrophy. In: D. Bergsma: First Conference on Clinical Delineation of Birth Defects. Skeletal dysplasias. Original Article Series, Vol. V, No. 4, p. 349. (National FoundationMarch of Dimes, New York, 1969).

14. Sensenbrenner, J. A., Kenyon, K. R., Thomas, G. H., And TAYLOR, H. A.: Mucolipidosis II (I-cell disease). In: D. Bergsma: Fifth Conference on Clinical Delineation of Birth Defects. Skeletal dysplasias. Original Article Series, Vol. XIX. (National Foundation-March of Dimes, New York, 1973).

15. Siggers, D., and Reynolds, C. W.: Mucolipidosis III. In: D. Bergsma: Fifth Conference on Clinical Delineation of Birth
Defects. Skeletal dysplasias. Original Article Series, Vol. XIX. (National Foundation-March of Dimes, New York, 1973).

16. Spranger, J. W., and Wiedemann, H. R.: The genetic mucolipidoses: Diagnosis and differential diagnosis. Humangenetik, 9: $113(1970)$.

17. Steinbach, H. L., Preger, L., Willyams, H. E., and Cohen, P.: The Hurler syndrome without abnormal mucopolysacchariduria. Radiology, 90: 472 (1968).

18. Strrerng, J. L.: Separation and characterisation of $N$-acetyl$\beta$-glucosaminidases $\mathrm{A}$ and $\mathrm{P}$ from maternal serum. Biochim. Biophys. Acta, 271: 154 (1972).

19. Taylor, H. A., Thomas, G. H., Miller, C. S., Kelly, T. E., AND SIGGERS, D.: Mucolipidosis III (pseudo-Hurler polydystrophy): Cytological and ultrastructural observations of cultured fibroblast cells. Clin. Gen. (In press).

20. Wiesmann, U., Vassella, F., and Herschiowitz, N.: "I-cell" disease: Leakage of lysosomal enzymes into extracellular fluids. N. Engl. J. Med., 285: 1090 (1971).

21. Zielke, K., OKada, S., and O'Brien, J. S.: Fucosidosis: Diagnosis by serum assay of $\alpha$-L-fucosidase. J. Lab. Clin. Med., 79: 164 (1972).

22. Numbers were assigned to patients by The Johns Hopkins Hospital.

23. Falcon Plastics, Division of Bioquest, Oxnard, Calif.

24. Chemetron, Gustavo Modena, 24 Milan, Italy.

25. The band designated as $\mathrm{I}_{2}$ by Price and Dance [10] appears to be identical with the $\mathrm{P}$ form of $N$-acetyl- $\beta$-D-glucosaminidase described by Stirling [18].

26. We wish to thank Drs. T. Kelly, J. Sensenbrenner, and D. Siggers for obtaining the clinical material needed for this study, and Mr. Steven Taback for expert technical assistance.

27. This study was supported by Project Grant No. 917 from Maternal and Child Health Service, Department of Health, Education and Welfare.

28. Requests for reprints should be addressed to: GeOrge $H$. THOMAS, Ph.D., The John F. Kennedy Institute, $707 \mathrm{~N}$. Broadway, Baltimore, Md. 21205 (USA).

29. Accepted for publication April 18, 1973. 